
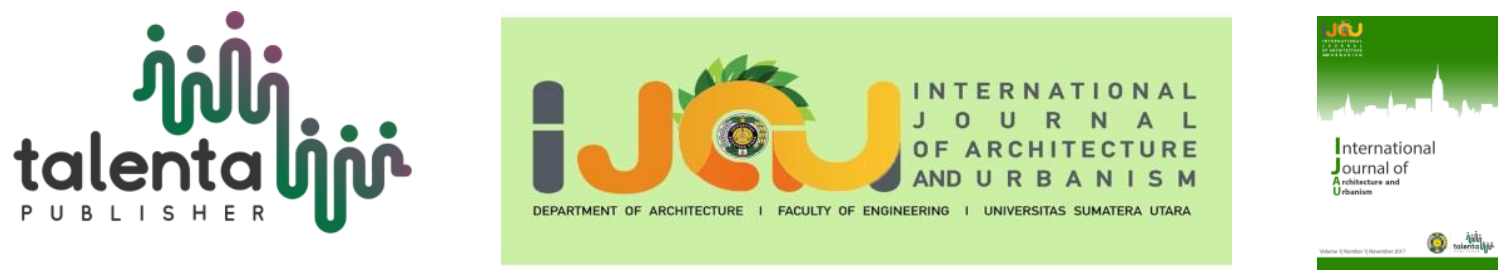

\title{
Local Satisfaction Study on Tourism activities in Pangururan District Samosir Regency
}

\author{
M.Emilsyah Insya ${ }^{1 *}$ \\ ${ }^{1}$ Department of Water Resources, Medan, Indonesia
}

\begin{abstract}
Local tourism administrations in traveler attractions in Pangururan Locale, in this case, precisely and in a roundabout way, influence the evaluation of the fulfillment and dependability of neighborhood communities within the zone. In this manner, it is essential to investigate and think about the impact of benefit fulfillment of neighborhood tourism exercises on traveler fulfillment and devotion in visitor attractions in Pangururan Locale. The benefit quality variable, which comprises coordinate prove, sympathy, responsiveness, unwavering quality, and confirmation, impacts sightseers' fulfillment and dependability. Respondents were visitors and neighborhood individuals who gone by and settled in Pangururan Locale, totaling 110 respondents with the client fulfillment file procedure. In this composing, data collection utilized perception procedures organized interviews, surveys, and writing. At that point, it was analyzed with Likert scale investigation, legitimacy, and unwavering quality tests: separate straight relapse investigation, relationship examination, and examination of assurance. Based on factual information investigation, the pointers in this ponder are substantial, and the factors are dependable. The quality of neighborhood visit direct administrations is sweet at $80 \%$, and $70.5 \%$ for visitor devotion. Whereas the rest is impacted by other variables which are not assist explored in this consider. Based on this examination, it can be concluded that there is a significant relationship between the quality of direct neighborhood administrations on the fulfillment and loyalty of visitors within the traveler attractions of Pangururan Locale. It is recommended to the chief that it is essential to hold special preparation for neighborhood guides to back the quality and convenience of human assets there to bolster traveler attractions in Pangururan Area, Samosir Rule
\end{abstract}

Keyword:community satisfaction; customer loyalty; satisfaction index

Received 29-12-2020 |Revised 16-1-2021 | Accepted 25-2-2021

\section{Introduction}

In general, tourism development aims to improve destinations' quality to attract tourists to visit according to their respective goals. The central government and local governments will work hard to develop tourism based on each region's tourism potential. Due to the following three points, tourism activities can develop: (1) the emergence of exotic tourism; (2) tourists' wants and needs; (3) fulfilling the political interests of the state authorities as a tourist destination.

\footnotetext{
*Corresponding author at:Department of Water Resources, Sakti Lubis, Medan 20217, Indonesia

E-mail address: emilinsya@gmail.com
}

Copyright $@ 2021$ Published by Talenta Publisher, 
Could say tourism is an activity for travelers. Most of the tourism activities are related to mobility, and the term tourism to travel, namely tourism activities. To attract tourists, it is also necessary to improve the management of tourism assets professionally, especially planning and natural and cultural structures; therefore, managers must understand tourists' characteristics and the attributes of tourism products related to tourist satisfaction. Tourism product attributes refer to tourism products as one of the objects provided by tourism marketing, which includes three parts: (1) Tourism attributes have potential natural tourist attractions based on the development of natural tourism. The main potential of natural resources (1). Nature and cubirthased tourism); (2) Facilities owned by tourist objects, including accommodation, food processing, parking lots, entertainment, (3) Ease of travel to tourist destinations. If there is a connection between tourism and a destination, tourists will travel [1]. The ideal tourist destination area mapped with tourists' facilities during the trip, such as catering services, accommodation, entertainment, shopping, and transportation, can take you to other tourist attractions. For tourists visiting tourist destinations to feel comfortable, it is necessary to provide tour package products according to tourists' needs and needs [2]. In terms of the origin of the tourist area and the intention to visit the object, tourists who visit tourist attractions are very diverse. The demands and demands of tourists on tourist facilities are also very diverse; therefore, in attracting tourists with various characteristics, tourism products' attributes must be diversified. Local satisfaction can have a significant impact on the sustainability of tourism in that place. According to the 2004 WTO, people satisfaction in tourist destinations worldwide is that traveling is to see monuments, activities, and habits of engaging local people to enjoy a different atmosphere from the city where they come from. This is because the people themselves become managers of natural tourist attractions or hosts for tourists who will come to these attractions. Bringing in tourists positively impacts the community from tourism activities through employment, economic activities, and increased social services. According to Indriastuty, N., Saputro, W. E., \& Sukimin, S. [3], tourist attraction through consumer satisfaction has a positive effect on the interest in revisiting, this affects the role of the community in carrying out tourism activities to improve the quality of tourism to keep tourists from reviewing these attractions. In making observations about local satisfaction related to sustainable tourism in Pangururan District, Samosir Regency is the level of community satisfaction and dissatisfaction. In this case, there is a need for information and innovation through technology to promote sustainable tourism, including collecting data on the role of local communities in tourism activities [4].

\section{Method}

To solve the problems described in the introduction, questionnaires were distributed at specific points along with audiences for the management of tourism to provide local satisfaction, which has a significant impact on tourism sustainability in Pangurruran District, Samosir Regency. Tourism and dissatisfaction in residents' number of complaints about tourism activities in 
Pangururan District, Samosir Regency. What is used in this research is a descriptive method with a quantitative approach through a Linkert scale by distributing questionnaires[5]. If necessary, a flowchart can be drawn for the implementation method similar to the rules for making a flow chart of an algorithm. The implementation of this research will be carried out in two major stages: Distribution / Distribution of the Questionnaire and Observation of specific areas. It is estimated that this activity will be carried out in December 2020. The methods that will be carried out in the implementation of this service are: Obtain data in the form of information taken from questionnaires, Identify how the administrative process in tourism management, To attract tourists interest, the readiness process of tourism management human resources is examined, Measuring the Level of Satisfaction [6].

\section{Result and Discussion}

The research/field survey was carried out in the tourist area of Panguruan District, the object in Samosir Regency. The object of research was visitors/tourists who came to the Pangururan object on data sourced from SIPD Samosir Regency in 2013 - 2018. The number refers to researchers' latest visit data when conducting a survey of visits in 2020. As many as 378,649 visitors were obtained from the Samosir regent's regulation which was written in the Samosir Regency RKPD 2020 when researchers visited Panguruan sub-district. In the context of research efficiency and effectiveness, sampling is carried out to represent the population. As a representative sample of the population, researchers used the Slovin Formula guidelines based on formula 1[7]. The formula for determining sample size is:

$$
n=N /\left(1+N e^{\wedge} 2\right)
$$

Where: $\mathrm{n}=$ Sample size $\mathrm{N}=$ population size $; \mathrm{e}=$ critical value or desired accuracy limit. Based on the formula above, with the number of visitors 30,986 people from the 2019 Central Bureau of Statistics, with a critical value or the desired accuracy limit of $10 \%$, the number of samples that meet the requirements is 105.5 . To facilitate calculation, the minimum number of samples taken is rounded to 110 people. To obtain the data needed for this research activity, the field data were collected by distributing questionnaires. The analysis technique used in this research is statistical analysis and the Customer Satisfaction Index.

Validity and Reliability Tests in Table 1 An analysis was carried out by testing the questionnaire's validity and reliability [8]. The question item is declared valid if it has a significant value below $10 \%(0.1)$. Based on data processing results, the questionnaire is valid because $r$ count $>r$ table. For the reliability test based on the Cronbach Alpha technique, the value of the reliability coefficient (Cronbach alpha) is 0.955 , which is greater than the $r$ table (0.1654), which means that the instrument of variable expectations is reliable and has high 
reliability[9]. The value of the reliability coefficient (Cronbach alpha) of 0.3 is greater than the $r$ table (0.1654), which means that the instrument performance variable is reliable and has high reliability in Figure 1.

Table 1 Validity Test Results Using SPSS

\begin{tabular}{|c|c|c|c|c|c|c|c|}
\hline \multicolumn{8}{|c|}{ Correlations } \\
\hline & & $\mathrm{P} 1$ & $\mathrm{P} 2$ & P3 & $\mathrm{P} 4$ & $\mathrm{P} 5$ & Total \\
\hline \multirow[t]{3}{*}{$\mathrm{P} 1$} & Pearson Correlation & 1 & .120 & -.081 & 0.54 & 0.516 & $.516^{* *}$ \\
\hline & Sig. ( 2 Tailed ) & & .213 & .401 & .572 & .814 & .000 \\
\hline & $\mathrm{N}$ & 110 & 110 & 110 & 110 & 110 & 110 \\
\hline \multirow[t]{3}{*}{$\mathrm{P} 2$} & Pearson Correlation & & & & & & $.411^{* *}$ \\
\hline & Sig. ( 2 Tailed ) & .120 & 1 & .050 & -.088 & -.153 & .000 \\
\hline & $\mathrm{N}$ & 110 & 110 & 110 & 110 & 110 & 110 \\
\hline \multirow[t]{3}{*}{ P3 } & Pearson Correlation & -.081 & .050 & 1 & .174 & -.089 & $.479^{* *}$ \\
\hline & Pearson Correlation & .041 & .601 & & .069 & .353 & .000 \\
\hline & $\mathrm{N}$ & 110 & 110 & 110 & 110 & 110 & 110 \\
\hline \multirow[t]{3}{*}{ P4 } & Pearson Correlation & .054 & -.088 & .174 & 1 & -.145 & $.438^{* *}$ \\
\hline & Pearson Correlation & .572 & .358 & .069 & & .132 & .000 \\
\hline & $\mathrm{N}$ & 110 & 110 & 110 & 110 & 110 & 110 \\
\hline \multirow[t]{3}{*}{ P5 } & Pearson Correlation & $.516^{* *}$ & $.411^{* *}$ & & $.479^{* *}$ & $.438^{* *}$ & 1 \\
\hline & Pearson Correlation & .000 & .000 & .000 & .000 & .000 & \\
\hline & $\mathrm{N}$ & 110 & 110 & 110 & 110 & 110 & 110 \\
\hline
\end{tabular}

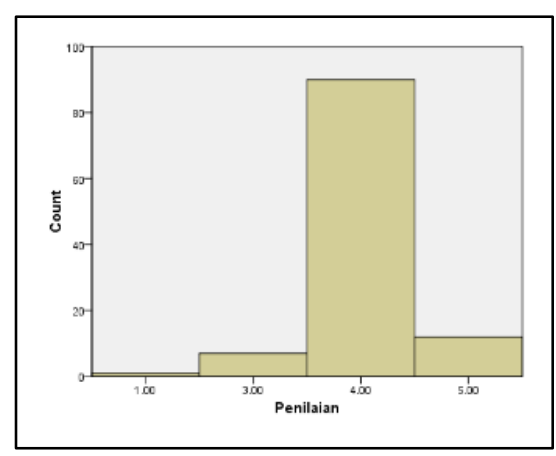

Figure 1 Graph of Assessment and Descriptive Statistics Test Results

The Customer Satisfaction Index (CSI) is used to determine the overall level of visitor satisfaction with an approach that considers the importance of the measured service quality attributes. The Chi-square test is a non-parametric statistical test. Because it is included in a non-parametric test, the Chi-square test can be applied for testing nominal and categorical data. It can be viewed in Table 2 .

Table 2 Statistical Results related to Good Tourism for Communities in Pangururan District

\begin{tabular}{lcc}
\hline \multicolumn{1}{c}{ Assessment } & Respondent & Percentage (\%) \\
\hline Strongly Agree & 12 & $10,9 \%$ \\
\hline Agree & 90 & $81,81 \%$ \\
\hline Disagree & 7 & $6,36 \%$ \\
\hline Neither disagrees & 1 & $0,90 \%$ \\
\hline Strongly disagree & 0 & $0 \%$ \\
\hline
\end{tabular}


To see the quadrants' location from these results, we will look for the intervals of each quadrant. The researchers used five quadrants, namely very bad, wrong, enough, high, and very high.

Ideal Score $=$ Highest Score Value $\mathrm{x}$ Number of Items $\mathrm{x}$ Number of Respondents $=2750$

Min Score $=$ Lowest Score Value $\mathrm{x}$ Number of Items $\mathrm{x}$ Number of Respondents $=550$

Interval $=($ maximum value - minimum value $)=440$

For example, Figure 2, Judging from the gradient that has been tested in Table 3, proves that the community assesses that it is sufficiently related to tourism, suitable for the people in Pangururan District [10].

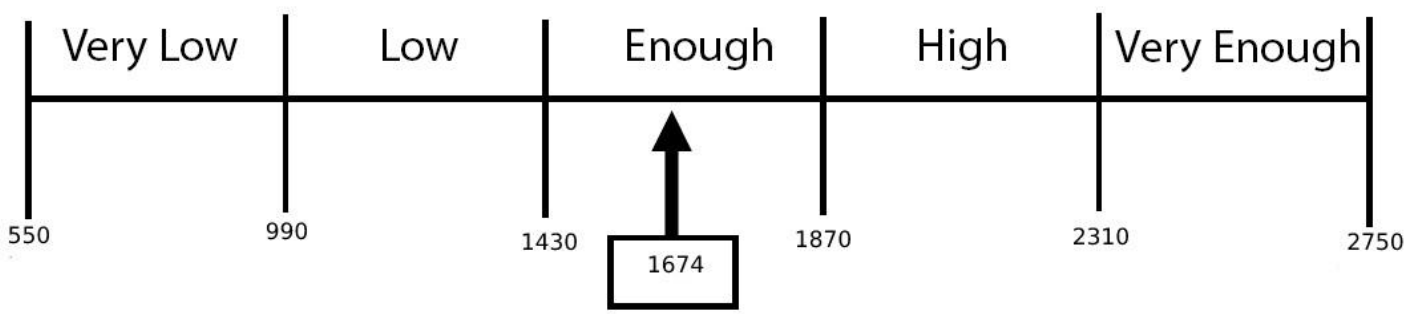

Figure 2 The location of the Tourism-related Satisfaction Index Gradient for the community

Table 3 Test Results of Satisfaction Index related to Good Tourism for Communities in Pangururan

\begin{tabular}{llllll}
\hline No. & Attribute & Score & $\%$ & Ideal Score & Index \\
\hline 1 & P1 & 327 & $19,53 \%$ & 550 & $59 \%$ \\
\hline 2 & P2 & 353 & $21 \%$ & 550 & $64 \%$ \\
\hline 3 & P3 & 328 & $19,59 \%$ & 550 & $59 \%$ \\
\hline 4 & P4 & 331 & $19,77 \%$ & 550 & $59 \%$ \\
\hline 5 & P5 & 335 & $20 \%$ & 550 & $60 \%$ \\
\hline & Total / Average & 1674 & $100 \%$ & 2750 & $60 \%$ \\
\hline
\end{tabular}

\section{Conclusion}

The study of the level of satisfaction of local communities with tourism activities in Pangururan District, Samosir Regency, is useful for improving the quality of visits to tourist objects by raising the side of community-based tourism[11]. The study regarding monitoring local community satisfaction with tourism activities is a step to develop tourism destinations in Pangururan District[12]. This analysis is also useful for making tourism a source of additional income and primary income without destroying the Pangururan District community's culture to improve the quality of life-related to the process of interaction with tourists. Satisfaction is when consumers feel after experiencing a performance (or result) that has met their various expectations[13]. Besides, satisfaction becomes a description of a person's level of feelings 
(customer) after comparing the performance or perceived results (services received and felt) with what they expect. Satisfaction is the level of someone's satisfaction after comparing the performance or perceived consequences and compared to their expectations. Thus, satisfaction or dissatisfaction is the conclusion of the interaction between expectations and experiences after using the services or services provided[14]. If the presentation is less than expected, the customer feels unsatisfied. However, if the representation displayed is proportional to expectations, the customer will be satisfied. If the quality of the presentation shown exceeds expectations, the customer will feel very satisfied or happy.

Based on the results of distributing questionnaires, statistical results were obtained, which stated that $10.9 \%$ strongly agreed that tourism was suitable for Pangururan District people. However, there are $0.90 \%$ who disagree with the existence of tourism for local people. Besides, $81.81 \%$ of respondents agree that tourism is good for the community in Pangururan District. As for some suggestions and problems from the problem of public dissatisfaction from the questionnaire conducted on tourism activities in Pangururan sub-district, namely: The existence of tourism objects is not well managed, (Management of Tourism Objects), Promotion of Tourism Objects in Pangururan District is very lacking, plus media information facilities very minimal and not up to date including the use of information through I.T. technology does not exist. The selling value of tourism to attract tourists to visit decreases (a tourist attraction in tourist objects) as a tourism destination, City Planning and Infrastructure are still minimal (Need for Infrastructure Improvements) including the presence of irregular parking areas, street lighting is very lacking, road signs and tourist attractions are not there/difficulty in knowing the existence of these tourist objects, There are still many natural resources that can become new tourist objects. The facilities and infrastructure are still inadequate such as hotels, mosques, restaurants, markets, and malls/supermarkets. Muslim restaurants are tough and far away from tourist sites.

WTO (2004) states about people's satisfaction with tourist destinations worldwide that traveling is to see monuments, activities and engaging habits of local people or to enjoy a different atmosphere from the city where they come from. The people themselves become managers of natural tourist attractions or hosts for tourists who will come to beaches, lakes, mountains, events, etc. The community gets positive impacts from tourism activities through employment, economic activities, increased social services, and adverse results due to stress or damage to local resources and cultural values. The satisfaction of the local community is essential for the sustainability of tourism in Pangururan District. In extreme cases, public hostility will encourage tourists to leave and never come again. The tourism industry's actions to maintain a positive relationship between hosts and tourists can anticipate and prevent incidents and adverse effects [15]. Considering that Pangururan tourism, which is still marketed until now, relies on natural potential and has the most dominant relationship with the satisfaction of tourists visiting Pangururan tourism objects; therefore to attract and increase the number of tourists, tourism 
attraction must be developed and packaged in such a way through a touch of art and culture. For example, by scheduling performances or art attractions regularly at Pangururan attractions. The facility factor has a relationship with tourist satisfaction; it can increase visitors' number; it is necessary to make or strive for all available facilities to make a tourist spot attract interest

\section{REFERENCES}

[1] Ayuningrum, Ika Dwi, and Edriana Pangestuti, 2018. Pengaruh Inovasi Terhadap Keunggulan Bersaing Dan Kepuasan Pengunjung Industri Pariwisata Di Kabupaten Bojonegoro. Jurnal Administrasi Bisnis 60 (1): 195-203.

[2] D. H. Wijaya, A. P, 2020. Mary, Rahmawati, TOURIST CHARACTERISTICS, TOURISM PRODUCT ATTRIBUTES, AND TOURIST SATISFACTION ON VISITING TOURISM OBJECT OF RAMMING-RAMMING LIMESTONE FOREST PARK, MAROS DISTRICT OF SOUTH SULAWESI, INDONESIA. Russian Journal of Agricultural and Socio-Economic Sciences. 3: 3-8.

[3] Girikallo, A. S., O. R. Payangan, Madris, and A. R. Laba, 2019. The Potential of Ecotourism Development through Community Involvement to Enhance Tourism Destination Performance in Tana Toraja (An Implementation of Ecotourism Concepts on Banua Tongkonan). In IOP Conference Series: Earth and Environmental Science. Vol. 235. Institute of Physics Publishing.

[4] He, Xiaoshan, and Jian Ming Luo, 2020. The relationship among Travel Motivation, Satisfaction and Revisit Intention of Skiers: A Case Study on the Tourists of Urumqi Silk Road Ski Resort. Administrative Sciences 10 (3).

[5] Indriastuty, Saputro, and Sukimin, 2020. Analisis daya Tarik Wisata, Persepsi Harga, dan Kualitas Pelayanan Terhadap Konsumen Sebagai Variabel Intervening. Jurnal GeoEkonomi 11 (1) : 56 - 73.

[6] Lee, Sean, Ian Phau, Michael Hughes, Yu Feng Li, and Vanessa Quintal, 2016. Heritage Tourism in Singapore Chinatown: A Perceived Value Approach to Authenticity and Satisfaction. Journal of Travel and Tourism Marketing 33 (7). Routledge: 981-98.

[7] Marlyana, Novi, and Nuzulia Khoiriyah, 2015. MODEL KONSEPTUAL PENINGKATAN KUALITAS LAYANAN INDUSTRI PARIWISATA DI JAWA TENGAH MENGGUNAKAN TOURSERVQUAL. Jurnal Kawistara 5 (2). Universitas Gadjah Mada.

[8] Rahayu S, 2018. Pariwisata Kreatif; Strategi Menghadapi Masyarakat Ekonomi Asean (Mea). Seminar Nasional : 416-423.

[9] Ludhiana, Dedi, and Dwi Hastuti Lestari Komarlina, 2018. Market Segmentation, Targeting Strategy and Positioning Strategy Performance Effects to the Tourists Satisfaction (Research in Pangandaran Beach Pangandaran District). International Journal 
of Scientific and Technology Research 7 (9). International Journal of Scientific and Technology Research: 67-76.

[10] Kusmayadi, and Endar S,2000. "Metodologi Penelitian dalam bidang Kepariwisataan. $P T$ Gramedia Pustaka Utama : 59-80.

[11] Saputra, and Ali K, 2020. Analisis Kebijakan Pariwisata Terhadap Pengelolaan Objek Wisata di Kabupaten Samosir. Seminar Nasional.

[12] Simarmata H, and Panjaitan N J, 2019. Strategi Pengembangan Pariwisata Berbasis Ekonomi Kreatif dalam Peningkatan Perekonomian Masyarakat Kabupaten Toba Samosir . Jurnal Ekonomi dan Bisnis 2 (2) : 189 - 201

[13] Sinaga, 2018. Aspek Inovasi dan Teknologi Dalam Pengembangan Kawasan Danau Toba di Kabupaten Samosir. Inovasi, 15(1) : 33-47.

[14] Suyono, Bambang, 2020. Analisis Kepuasan Wisatawan Telaga Sarangan Magetan Berdasarkan Tourism Experience. JURNAL EKOMAKS: Jurnal Ilmu Ekonomi, Manajemen, Dan Akuntansi 9 (1). LPPM Universitas Merdeka Madiun: 39-43.

[15] Wijaya, D.H., A.P. Ery, and Rahmawati, 2020. TOURIST CHARACTERISTICS, TOURISM PRODUCT ATTRIBUTES, AND TOURIST SATISFACTION ON VISITING TOURISM OBJECT OF RAMMING-RAMMImentfulNG LIMESTONE FOREST PARK, MAROS DISTRICT OF SOUTH SULAWESI, INDONESIA. Russian Journal of Agricultural and Socio-Economic Sciences 3 (99). Russian Journal of Agricultural and Socio-Economic Sciences: 3-8. 